\title{
METHODOLOGICAL PRINCIPLES OF PREPARATION OF PHILOLOGY TEACHERS FOR THE IMPLEMENTATION OF INTERCULTURAL COMMUNICATION
}

\author{
Tetiana Tarasenko, Liudmyla Kulykova, Natalia Hostischeva, Tetiana Riabukha
}

Melitopol Bohdan Khmelnitsky State Pedagogical University

\begin{abstract}
Resume:
The article is devoted to the methodological foundations of preparing the intending philologists for the implementation of crosscultural communication. Based on the analysis of various sources, the essence of the concepts "crosscultural communication", "crosscultural communicative competence", the main conditions for successful intercultural communication are revealed. It is determined the ways of formation of the «secondary linguistic personality » of the intending teacherphilologist for effective cross-cultural communication, taking into account the increase in the level of methodological training of a specialist. This training is provided by the organization of educational process in a higher pedagogical educational institution on the basis of communicative-active and culturological approaches by disclosing the creative potential of a student identity. The educational process is carried out through the means of a foreign language, selfsearch activities, learning cultures of native and English-speaking countries and comparing these countries through the prism of the language, using the potential of Internet technologies. Internet is a tool to intensify the educational process and unrestricted access to authentic sources, a tool of using the potential of a foreign language lesson to accomplish tasks that imply the ability of the intending philologists to apply situations with the domination of problematic, communicative tasks and reliance on a functionally adequate text.
\end{abstract}

\section{Key words:}

cross-cultural communication, personality of a teacher-philologist, methodological training, communicative activity, crosscultural competence, dialogue of cultures, realization of pedagogical conditions.
Анотація:

Тарасенко Тетяна, Куликова Людмила, Гостіщева Наталя, Рябуха Тетяна. Методичні засади підготовки майбутніх учителів-фрілологів до здійснення міжкультурної комунікації.

У статті висвітлено методичні засади підготовки майбутніх фрілологів до здійснення ними міжкультурної комунікації. На основі аналізу різних джерел розкрито сутність понять «міжкультурна комунікація», «міжкультурна комунікативна компетентність» та виявлено головні умови успішної міжкультурної комунікації. Визначено шляхи формування «вторинної мовної особистості» майбутнього вчителяфілолога для здійснення ефективної міжкультурної комунікації з огляду на підвищення рівня методичної підготовки фахівця. Таку підготовку здатний забезпечити вищий педагогічний навчальний заклад, навчальновиховний процес у якому організовується на засадах комунікативно-діяльнісного та культурологічного підходів і передбачає: розкриття творчого потенціалу особистості студента засобами іноземної мови; самостійну пошукову діяльність; вивчення культури рідної та англомовних країн і порівняння цих країн через призму мови; використання потенціалу інтернет-технологій як інструменту інтенсифікації навчального процесу й необмеженого доступу до автентичних джерел; використання потенціалу занять з іноземної мови для реалізації завдань, виконання яких передбачає здатність майбутніх філологів до створення ситуацій з домінуванням проблемних, комунікативних завдань і з опорою на функціонально адекватний текст.

\section{Ключові слова:}

міжкультурна комунікація; особистість учителя-фрілолога; методологічна підготовка; комунікативна діяльність; міжкультурна компетентність; діалог культур; реалізація педагогічних умов.

\section{Аннотация:}

Тарасенко Татьяна, Куликова Людмила, Гостищева Наталья, Рябуха Татьяна. Методические основы подготовки будущего учителя-филолога к осуществлению межкультурной коммуникации.

Статья посвящена методическим основам подготовки будущих филологов к осуществлению межкультурной коммуникации. На основе анализа различных источников раскрыта сущность понятий «межкультурная коммуникация», «межкультурная коммуникативная компетентность», выявлены главные условия успешной межкультурной коммуникации. Определены пути формирования «вторичной языковой личности» будущего учителя-филолога для осуществления эфффективной межкультурной коммуникации с учетом повышения уровня методической подготовки специалиста. Такую подготовку может обеспечить высшее педагогическое учебное заведение, учебно-воспитательный процесс в котором организован на основе коммуникативно-деятельностного

и культурологического подходов и предполагает: раскрытие творческого потенциала личности студента с помощью средств иностранного языка; самостоятельную поисковую деятельность; изучение культуры родной и англоязычных стран и сравнение этих стран через призму языка; использование потенциала интернеттехнологий как инструмента интенсификации учебного процесса и неограниченного доступа каутентичным источникам; использование потенциала занятия по иностранному языку для реализации задач, выполнение которых предполагает способность будущих филологов создавать ситуации с доминированием проблемных, коммуникативных задач и с опорой на функционально-адекватный текст.

\section{Ключевые слова:}

межкультурная коммуникация; личность учителя-фрилолога; методологическая подготовка; коммуникативная деятельность; межкультурная компетентность; диалог культур; реализация педагогических условий.
Formulation of the problem. Modern society has entered a period of radical changes associated with its high degree of development, the processes of globalization and integration, the continuous expansion of the spheres of international and interethnic communication. Obviously, further development of mankind is possible only under the dialogue of representatives of different nationalcultural communities that can understand and accept another culture as equivalent to their own native culture.

The ability to cross-cultural communication at the present stage of integration of educational systems is considered as a leading personal and professional characteristic of a modern specialist. Since the language serves as the main tool of international communication, the success of the professional activity of the teacher-philologist is largely 
determined by the level of formation of skills of cross-cultural communication, which is considered as an integrative individual property, which ensures the success of the professional activity of a specialist. In light of the above, modern Ukrainian higher education faces the problem of preparing a teacherphilologist for a new Ukrainian school, not only capable of effective inter-ethnic cooperation, but also able to instill skills of cross-cultural communication to his students.

Analysis of recent research and publications. The theoretical basis for determining the ways of solving this problem is the work devoted to the concept definition of «cross-cultural communication» (E. Goll, G. Traiger); psychological and pedagogical research on problems of cross-cultural communication (T. G. Grushevitska, O. P. Sadokhin, S. G. Ter-Minasova); pedagogical ideas of integration (V. I. Zagviazinsky, V. O. Slastonin) and the humanization of education (B. G. Ananiev, I. O. Zimnia); the didactic concept of the education content as the basis for creating a technology for forming skills of cross-cultural communication from the standpoint of integration (I. Y. Lerner, M. N. Skatkin); the question of the effectiveness of foreign cross-cultural communication, idiomatic and stylistic adequacy of speech (L. P. Smeliakova, G. I. Podosinnikova, V. M. Topalova). The methodological basis are communicative-active and cultural approaches.

As the experience of higher education shows, cross-cultural communication is not yet sufficiently used in the practice of teaching a foreign language. This is primarily due to the limited ability of Ukrainian graduates to communicate with colleagues from other countries (during the practice, attending conferences, seminars). It is possible to solve this problem by intensifying the use of modern information technologies and the latest methods of training. Therefore, the relevance of the article is evident at the present stage.

Formulating the goals of the article. The aim of the article is to substantiate the feasibility of using modern information and communication technologies and the latest methods of teaching at foreign language lessons in order to prepare intending teachers of philology for the implementation of cross-cultural communication.

Today, the purpose of teaching a foreign language involves not only the study of language as a «form for the expression of external content», «as a system of signs», «information code», but also as a phenomenon, that is closely related to human activity and culture, since language as a social phenomenon can not exist without man. The reorientation of teaching a foreign language to a communicative foreign language education sets for the student new goals and objectives aimed at mastering a foreign language communication.

Presentation of the main research material. Even the philosophers of the ancient world considered the relation of language and culture and noted the active role of language in the development of culture, the achievement of scientific truths. Having formed in society, language contributes to the flowering of culture, reflects the national psychology, sociohistorical conditions of life and cultural characteristics of the people. It is logical that the language as a means of communication acts as an instrument of transferring the cultural values of the people speaking this language. Thus, the language is as «a component of spiritual culture, a necessary means of human thought and communication, a condition for emergence and development of these people, as well as the transfer of cultural values from generation to generation» [9]. Thus, linguistic education as a result of mastering communicative competence involves not only the formation of the ability of students-philologists to practical use of the language being studied, but also the mastering the ability to understand the bearer of another world view and communicate with him. That is, the result of linguistic education is a deliberately formed secondary linguistic person with large background knowledge of the country, language of which is studied.

To understand the behavior of a representative of another culture and respond him adequately in a particular situation, one needs to know what behavior is traditional and common in this culture, because each culture has its own specific model of socially acceptable and appropriate behavior that is effective in achieving the goals of communication (interaction). Therefore, in order to learn a foreign culture of communication, it is necessary to develop cross-cultural competence and teach communicative behavior from the initial stage of teaching a foreign language.

The beginning of the 21st century is characterized by a revision of the fundamental foundations of linguistic education. Modern geopolitical, geoeconomic and geocultural situations require the introduction and use of innovative technologies in the system of language education that contribute to the formation of a «secondary linguistic personality». According to E. Goll, who together with G. Treiger in 1959 first proposed the main principles of the theory and the term «intercultural communication», the main purpose of teaching foreign languages is to teach the language as a real and excellent means of communication [11].

Important aspects of cross-cultural communication are such concepts as «culture», «socialization», «communication». 
Culture is a way of thinking and life, through which a person receives a set of views, values, norms and beliefs that are taught and supported by other members of the group. This set of basic assumptions and solutions to the problems of the world is a common system that is passed from one generation to the next to ensure survival. Culture consists of unwritten and written principles and laws that govern how a person interacts with the outside world. The members of any culture can be identified by the fact that they share some similarities. They can be united by religion, geography, race or ethnicity.

Socialization is a term used by sociologists, social psychologists, anthropologists, political scientists and educators to get acquainted with the process of inheritance and the spread of norms, customs, values and ideologies that provide the individual with the skills which are necessary to participate in their own society. Thus, socialization is «a means of achieving social and cultural continuity» $[5, \mathrm{p} .8]$.

Socialization describes a process that can lead to desired results - sometimes labeled as «moral» - in relation to the society in which it occurs. Individual views on certain issues, such as race or economics, are influenced by social consensus and are usually subject to what society perceives to be acceptable or «normal». Many socio-political theories argue that socialization provides only a partial explanation of human beliefs and behavior, arguing that people are not empty sheets defined by their environment. Scientific research suggests that people are formed both by social influences and by genes. Genetic studies have shown that the human environment interacts with its genotype to influence behavioral implications.

Communication (from Latin commūnicāre, «share») is a purposeful activity of information exchange between two or more parties to transfer or obtain desired values through a common system of signs and semiotic rules. The main stages of communication are: the formation communicative intention, the composition of messages, message encoding and signal transmission, receiving a signal, decoding messages and, finally, the interpretation of the message by the recipient.

All communication is cultural - it relies on the ways in which people learned to speak and give nonverbal messages. Every day people do not always communicate the same way, because factors such as context, individual personality and mood interact with the various cultural influences that people have learned, and this affects their choice. Communication is interactive, so the important impact on its effectiveness is the relationship of people with others. In the process of contacts with individuals who use other cultural norms in their behavior, awareness of the characteristics of their own culture is realized. Often this kind of interaction causes discomfort and creates situations of conflict that requires a thorough study $[4$, p. 43].

In the process of cross-cultural communication, each person at the same time solves two most important problems - strives to preserve his cultural identity and engage in a different culture. The combination of possible solutions to these problems defines four basic forms of cross-cultural communication: direct, indirect, mediate and unmediate. For direct communication, the information is addressed directly from the sender to the recipient. It can be done both verbally and in writing. In direct communication, the greatest effect is achieved through oral speech, combining verbal and nonverbal means. In indirect communication, which is mostly one-sided, information sources are works of literature and art, radio reports, television broadcasts, publications in newspapers and magazines, electronic media, etc.

Cross-cultural communication refers to communication between people that are distinguished by one of the following features: work style, age, nationality, ethnicity, race, gender, sexual orientation, etc. Cross-cultural communication in the broadest sense is also used to describe attempts to exchange, discuss and mediate cultural differences through language, gestures and body language. It is through intercultural communication that people belonging to different cultures communicate with one another. In a purely scientific sense, cross-cultural communication is a hybrid branch of academic disciplines that combines cultural anthropology, sociology and international studies focused on ways to facilitate understanding across borders and cultures.

Taking into account the purpose of our article, which is the professional training of intending philology teachers (specialists who learn the culture of another nation and instill it into the younger generation by means of a foreign language), we will consider cross-cultural communication as a special form of communication between two or more representatives of different cultures, during which there is an exchange of information and cultural values of interacting cultures. The process of crosscultural communication is a specific form of activity that is not limited only to the knowledge of foreign languages, but also requires knowledge of the material and spiritual culture of another nation, religion, values, moral attitudes, ideological notions, etc., which collectively determine the model of behavior of communication partners. Only the combination of two types of knowledge - language and culture - provides, in the opinion of O. P. Sadokhin, effective and fruitful communication [7].

The researcher divides the component elements of cross-cultural communication into: 
- affective (tolerance, empathy);

- cognitive (cultural-specific knowledge that promotes mutual understanding);

- procedural (communication strategies, which include the beginning of conversation, language cliche, etc., that are inherent in another culture) [7].

Information constituting the content of the communication process does not exist in isolation, but inextricably interconnected with the cultural world view that exists on each side. Together, the cultural world view and communicative information form the context of the communication process. It is accepted to allocate the internal context and the external context.

An internal context is a set of background knowledge, values, cultural identity and individual characteristics of the individual. It is also possible to relate the mood with which the communicator enters communication and which forms the psychological atmosphere of communication. The external context of communication is time, scope and conversation. An important point is the place of communication, which determines the background of the communicative process.

Expansion of international relations of Ukraine and deepening of European integration processes have caused significant changes in the field of teaching foreign languages, the status of which in our country is constantly increasing. At the present stage of the development of content of foreign education, an active introduction of a competent educational paradigm is taking place. It considers a foreign language not only as a means of interpersonal communication, but also cross-cultural communication.

Appeal to a competent paradigm in the process of teaching a foreign language is due to a number of objective circumstances, among which the most significant are the ability to coexist in the general living space, which means to be able to build a dialogue with all individuals of this space, be able to establish humanitarian cross-cultural connections between representatives of different cultures and countries. An important role in this is played by a foreign language, which appears to be the only possible tool by which the realization of the links of mutual understanding and interaction between representatives of various linguistic and social communities becomes real.

In the context of a competent educational paradigm developed by scholars on the basis of the European Recommendations on Language Education (2001), a student must not simply master the use of a foreign language as a means of communication, but act as a social agent, that is, a member of a society capable of fulfilling certain tasks in living conditions and the socio-cultural environment. Therefore, when learning the language, attention is also given to cognitive, emotional, volitional and other individual qualities and abilities of the language user as a representative of the society [10, p. 9]. The knowledge and skills that a student acquires in the process of foreign education gives him the opportunity to reach a certain level of development of communicative competencies - the necessary components of cross-cultural communication, through which his competence as a language user is formed. In this regard, the goal of modern teaching of foreign languages in higher schools is the formation of cross-cultural communicative competence of students, which includes language and linguistic, socio-cultural and sociolinguistic, discursive and strategic competences. The high level of development of such competence enables the students to increase mobility and increase the chances of employment.

Students should acquire the following skills in real life conditions of cross-cultural foreign communication: 1) to use a foreign language (in all its manifestations) in authentic situations of crosscultural communication (process of formation of skills and abilities); 2) to explain and assimilate (at a certain level) another way of life / behavior (processes of knowledge); 3) to expand the individual world view by attracting to the linguistic world view the native speakers of the language being studied (processes of development) [3, p. 19].

From the list of skills we can conclude that crosscultural communicative competence as a part of the goals of modern foreign education serves an integrative whole and includes in its content educational and developmental aspects of teaching a foreign language.

Knowledge that is necessary for successful crosscultural communication is divided into specific (knowledge of a particular culture) and general (tolerance, empathy, knowledge of general cultural universals) [7, p. 45]. The main and obligatory features of readiness for intercultural communication are:

- openness to the knowledge of another's culture and the perception of psychological, social and other intercultural differences;

- psychological mood for cooperation with representatives of another cultures;

- ability to distinguish between collective and individual in communicative behavior of representatives of other cultures;

- ability to overcome social, ethnic and cultural stereotypes;

- possession of a set of communicative means and their correct choice depending on the situation of communication;

- adherence to etiquette standards in the communication process. 
Accordingly, cross-cultural competence in its essence acts as a complex phenomenon, which includes linguistic, sociocultural, sociolinguistic, social, discursive, strategic competence, as well as such knowledge and experience of cross-cultural communication that provide the formation of a «secondary linguistic personality».

By the mid-1980s, western science had the idea that cross-cultural competence could be mastered through the knowledge gained in the process of crosscultural communication. Knowledge of this kind was divided into specific, which were defined as information about a particular culture in traditional aspects, and common, which included the possession of such communicative skills as tolerance, empathy listening, knowledge of general cultural universals.

The main goal of any communicative process is the desire to be understood by your partner, which implies the need to maximally complete and accurately convey your information, knowledge and experience to the interlocutor. For understanding, a set of knowledge, skills and abilities common to all communicants is required, as well as a positive attitude to the presence of various ethno-cultural groups. This set is cross-cultural competence, which implies readiness to conduct dialogue on the basis of knowledge of one's and another's culture, ability to navigate in partner's time and space, his social status, in ctoss-cultural differences, using different language forms (professional vocabulary, jargon, formal / informal styles) [2, p. 18].

Since the formation of cross-cultural competence is an integral result of education and upbringing based on dialogue between cultures, the psychological and pedagogical conditions and the mechanisms of its formation should be found on the components of personality, among which we can distinguish [8, p. 129]:

-cognitive component (knowledge about cultural and universal human spiritual values, relations, events, phenomena, processes, culture and spirituality of the people);

- value-normative component (interests, views, social settings, value orientations, beliefs, moral and ethical principles and norms of the personality);

- moral-volitional component (positive motives of activity and behavior, sense of duty and responsibility, will and purposefulness, setting on productivity, parity and cooperation, consensus and compromise, social activity, etc.);

- socially cultural component (development and engaging in culture, spirituality, values, traditions of own nation and other people).

There are the following ways of forming crosscultural competence:

-to understand the peculiarities of native and foreign culture;

-to replenish knowledge about different cultures;
- to gain knowledge about socio-cultural forms of interaction in a foreign culture.

In cross-cultural competence the language, communicative and cultural levels are distinguished [8, p. 26]. Language competence provides the right choice of linguistic means, adequate communication situations and the ability to apply the past communicative experience in new situations. Language competence is always higher in the native language than in the foreign language. Lack of verbal means when it is necessary to communicate in a foreign language is a strong incentive to improve language skills. It should be noted that the factor of linguistic competence in cross-cultural communication has a relative character, as in assessing the language competence of representatives of different cultures different criteria are used; different cultures may not coincide with the idea of what is right or wrong in terms of speech use; the assessment of the level of competence differs depending on the goals of communication (people can communicate well in a foreign language at the everyday level, but do not have sufficient competence to communicate at a professional level).

Cultural competence is the understanding of background knowledge, values, psychological and social identity characteristic of the cultural environment of communication. It provides the ability to extract the necessary information from various cultural sources (books, films, periodicals, political phenomena, etc.) and differentiate it from the point of view of significance for cross-cultural communication.

The communicative competence includes the techniques and strategies that are necessary for effective communication. Its constituent elements are the following skills:

-to interpret the signals that are specific to the culture of the willingness of the interlocutor to start the communication or unwillingness to communicate;

-to determine the proportion of speaking and listening, depending on the situation and cultural norms of the communication environment;

- to express own opinion adequately and understand the opinion of the interlocutor;

- to send the conversation in the right direction;

-to submit and interpret signals of changes in communicative roles and signals of the completion of communication;

-to preserve the communicative distance accepted for this culture;

-to use verbal and nonverbal means, acceptable for this culture;

-to adapt to the social status of communicants and cross-cultural differences;

-to correct own communicative behavior. 
A new model of the educational process is to create the conditions for the formation of key competences of a future specialist. According to the current definition, key competence is a system of universal knowledge, skills, as well as the experience of unaided activities and personal responsibility of students. So, speaking of linguistic education, the key competencies can be considered as such knowledge and experience of cross-cultural communication, which serve the purposes of forming a «secondary linguistic personality».

The modern educational process is aimed at developing the ability of students to be an effective participant in cross-cultural communication during its connection through various channels of communication to a new social reality for him. This can be achieved through the purposeful formation of socio-cultural competence of students-philologists, which includes a set of linguistic, country studies and socio-cultural knowledge not only of its own culture, but also of the culture of the country, the language of which is being studied, helping to achieve successful cross-cultural communication. The achievement of an adequate understanding of the participants in a communicative act is possible if they have the same background knowledge. In other words, the participant in cross-cultural communication must know and understand what the partner in communication talks about. The formation of background knowledge for future teachers of philology is one of the main tasks of professional training, since the availability of background knowledge is the main component of the formation of secondary linguistic personality.

Thus, the formation of a globalized and information-dependent society requires the implementation of a new paradigm of higher education based on the principles of humanism. Modern geopolitical, geoeconomic and geocultural situations require the introduction and use of innovative technologies in the system of foreign language education, which contribute to the formation of «secondary linguistic personality». During the training of the future philologist for crosscultural cooperation, a self-awareness training should be used, in which the person knows the cultural principles of his own behaviour; cognitive training, in which students are given information about different culture; attribution training that teaches to characterize situations that explain behaviour in terms of different culture. There is also an effective training based on the play of the proposed conflict situations. In order to prepare for cross-cultural cooperation, so-called cultural assimilators have become widespread in many countries. Their goal is to teach a person to see the situation from the point of view of the members of another group, to understand their vision of the world. A new model of educational process is to create conditions for the formation of key competencies, in particular, intercultural competence. Formation of background knowledge of future philologists is one of the main tasks of professional training, since the availability of knowledge is the main component of the formation of secondary linguistic personality.

In recent decades, the education system has undergone significant changes through the development of new technologies that have penetrated all spheres of life, simplifying and accelerating the process of interpersonal and business communication not only within Ukraine but also abroad. Information communication learning technologies are the main tools for the formation of cross-cultural competence of students of philology and help them to become effective at cross-cultural communication, especially in the absence of personal travel abroad for speech practice. The use of modern technologies, in particular the Internet, when learning foreign languages becomes more attractive for students of higher education institutions, giving them unlimited access to interesting study materials, which differ favourably from static outdated texts in textbooks. With the Internet future philologists have access to unlimited number of authentic foreign language information.

According to V. V. Bezludna software along with the use of the Internet and special computer programs become an integral part of the learning process. To this group of technologies the researcher includes such specialized programs as:

- computer courses (Reward, The Business);

- electronic dictionaries and translators (Macmillan English Dictionary, Lingvo, Prompt);

-test cases, with the possibility for the teacher to create their own tests;

-professional software, the example of which is the program Power Point, used for the preparation of presentations, slide shows and PR-actions, the creation of a portfolio [1].

The use of the Internet and other technologies provides great opportunities for the teacher when:

- searching for additional material - the teacher can refer to the existing specialized sites and find more material, saving time;

- preparing tasks - for example, use of electronic Macmillan English Dictionary for lexical exercises and interpretation of words in English;

- checking individual tasks (writing e-mail or business letter and sending it electronically to the address of a teacher or another student with the possibility of receiving an answer);

- improving methodological work (creating a manual with audio material, recording the speech or involving speakers of the language, using professional programs such as Adobe Audition). 
One of the most effective ways of activating students in the process of foreign language learning is the Task Based Learning (TBL) technology, a learning method of communication tasks, which was launched in the 80 's of the $20^{\text {th }}$ century as opposed to the traditional Presentation, Practice, Production (PPP) approach - a three-step model consisting of explanation, exercise and practical application. Despite its effectiveness and reliability, this approach does not take into account individual needs and peculiarities of the student, as tasks tend to be pseudo-communicative and focus on the development of lexical or grammatical material. In contrast, TBL considers language not as a set of lexical and grammatical phenomena, but as an instrument for achieving certain goals, similar to the use of native language in everyday life, where it is primarily a means of communication.

Within the framework of this technology, it is important to provide students with a communicative task in order to ensure their active participation, picking an interesting topic for discussion, which motivates them and causes an internal need for communication, and thus contributes to the most effective development of speech. What is a communicative task? Carrying out the game, solving the problem and exchanging information can be considered as an urgent task for TBL only if we avoid total concentration on structures and forms. This approach does not mean ignoring the correctness of the language, tasks must have an appropriate level of complexity, and their implementation must require the use of all acquired knowledge and skills in a foreign language and give students full freedom of choice of language means. Therefore, the tasks in which students receive a list of words or structures that need to be taken or a dialogue in which they only play their roles are not TBL-based. However, a roleplaying in which to find the right solution to a problem or to reach agreement on certain issues can be considered a real communicative task.

T. M. Naumenko notes that the role-playing helps to realize the main methodological principle - the communicative orientation of education, promotes students' motivation to learn a foreign language, allows to take into account the psychological and age features of students, their interests and inclinations, the scope of their activities, modelling the situations of real communication $[6$, p. 5]. The role-playing activates the students' desire for contact with each other and the teacher, creates conditions for equality in the language partnership, destroys the barrier of communication and gives the opportunity to speak unsure students and thus to overcome the language barrier. In the role-playing everyone gets a role and must be an active partner in language communication. In games students master such elements of communication as the ability to start a conversation, keep it going, interrupt the interlocutor, at the right moment to agree or disagree with his opinion, the ability to listen to the interlocutor, ask questions and so on. Almost all the time in the role playing is given to speech practice, while not only the speaker but also the listener is as active as possible, since he must understand and remember the partner's replica, correlate it with the situation, determine how much it meets the requirements of intercultural communication. Consequently, the key requirement for Task Based Learning technology is to set a goal that needs to be achieved in the communication process. In this case, the language is assimilated not as a set of linguistic phenomena, but as if in a «social context», that is, it is associated with the situation of communication, in which certain lexical and grammatical units are typically used by native speakers. Language learning takes place in the process of communication and interaction, which promotes the development of students' language competence [12].

The effective process of preparing future teachers of Philology for the implementation of cross-cultural communication is determined by the complex of the following pedagogical conditions:

- organization of interpersonal interaction and mutual understanding between the teacher and students, between students - representatives of different cultures within the group, faculty and university;

- inclusion of a student-philologist in practical cross-cultural communicative activities, in which the student's professional and creative potential is actualized and formed;

- continuous development and complication of speech activity.

The following pedagogical tools, forms and methods of work with students are considered effective for the professional study of a foreign language in order to implement intercultural communication:

1. Disclosure of the creative potential of the student's personality. Innovative models are used to create the pedagogical conditions for active learning and the development of creative potential of students. The development of information culture in students is considered to be leading in language learning. Students tend to self-knowledge and to selfimprovement, so it is expedient to develop intellectual self-regulation in them. Collective work (pair, group) also contributes to the development of each student. For example, dialogue speech is better trained in debates and discussion of situations: Chances of Success, Education Abroad or in Ukraine? Youth in Ukraine \& GB / the USA, World in Action; in role-playing games / scripts: Making Social Arrangements, Sharing a Flat, Designing a Holiday Abroad, Planning a TV Program 
(geographic, cultural or historical aspect), Giving Health Advice, Making a Deal; in modeling business communication: Choosing a Profession, Pedagogical Practice, Start a Language School; in simulation games (for example, after watching a video). Written language is formed using innovative techniques such as Conference Approach to Writing, Writing Strategies and Procedures, Language Arts Today, Guided Practice; Grammar, Mechanics and Curriculum Connections, Thinking Like a Writer, Reading-Writing Connections. Language clubs, video reviews, followed by discussions of films involving foreigners, and practical lessons on the system of two teachers (from Ukraine and the English-speaking country) proved themselves to work well in practice.

2. Study and comparison of the culture of native and English-speaking countries. Textbooks, that have a modular presentation of material with video and audio accompaniment, add to the formation of world outlook and awareness of students: introduce the achievements of universal culture and national mentality in the general, situational and cultural dimensions.

3. The potential of Internet technologies as a tool for intensifying the educational process. In order to facilitate the search for the necessary data in the flow of information, the teacher should plan courses of the thematic modules to motivate the students to study the algorithm for finding the necessary information; refer to additional information sources online and various search engines.

4. Authentic literature is a source of knowledge. The dynamics of the formation of professional knowledge occurs in the process of working with authentic material. We consider it useful to prepare an algorithm of socio-cultural analysis of the text for the perception and decoding of its content. Also the «Whole Language» method helps to learn the components of language and culture in the context of a whole literary text or microtext content of different nature.

5. The use of the potential foreign language classes for the realization of tasks involves the ability to apply situations with the predominance of problematic communicative tasks and basing on functionally adequate text.

6. Self-study student's research work significantly increases the level of his cognitive interests, teaches him to obtain knowledge and forms a habit and a desire to study constantly. The research has shown that the project design method (Topic Projects), which involves the joint work of several students, is promising as it ensures the integrity of student competence development.

7. The correlation and comparison of countries through languages. People are becoming highly mobile socially and geographically in order to to obtain quality education by combining several models of learning, gaining experience and better employment. The need for long-term training is the essence of lifelong learning.

Conclusion. Consequently, cross-cultural communication refers to the interaction of individuals, groups or organizations belonging to different cultures. In the scientific sense, cross-cultural communication is a hybrid branch of academic disciplines that combines cultural anthropology, sociology and international studies focused on ways of facilitating understanding across borders and cultures. The components of cross-cultural communication can be divided into affective (tolerance, empathy); cognitive (cultural-specific knowledge that promotes mutual understanding); procedural (communicative strategies that include the beginning of a conversation, language cliches inherent in another culture). The effectiveness of the process of cross-cultural communication ensures the appropriate competence of the speaker. In the light of modern European educational trends cross-cultural communicative competence as the main goal of foreign language education is an indicator of the formation of the human ability to act effectively in intercultural communication. Cross-cultural competence is a set of knowledge, skills and abilities, through which a person can successfully communicate with partners from other cultures, both on a routine and on a professional level. The formation of cross-cultural competence is an integral result of education and upbringing on the basis of the dialogue of cultures, so psychological and pedagogical conditions and mechanisms of its formation should be based on the components of personality. For the successful preparation of future philologists for the implementation of foreign communication and the formation of their crosscultural competence, it is necessary to organize interpersonal interaction and mutual understanding between the participants of the educational process, to include the student-philologist in practical crosscultural communicative activities, to develop continuously and complicate the speech activity. It is possible to achieve this by revealing the creative potential of the student's personality through the means of a foreign language, independent search activity, studying the culture of native and Englishspeaking countries, and comparing these countries through the prism of language, the use of the potential of Internet technologies as an instrument for the intensification of the educational process and unrestricted access to authentic sources, the use of the potential of foreign language classes for the implementation of tasks, the implementation of which involves the ability of future philologists to apply situations with the domination of problem and communication tasks and based on functional, adequate text. 
The prospect of our further research is seen in the study of interdependence and the close connection between teaching foreign languages and cross-cultural communication. Taking into account the theories, it is worth considering the problem of misunderstanding in the process of cross-cultural communication.

\section{References}

1. Bezliudna, V.V. (2017). Modern technologies of teaching foreign languages at a high school. Mova $i$ svit: suchasni tendentsii vykladannia inizemnyh mov $u$ vyschii shkoli: Proceedings of All-Ukrainian webinar, 29 November 2017. URL: http://eprints.zu.edu.ua/25927/20-\%20Kravets.pdf. [in Ukrainian]

2. Bielaia, E. N. (2011). Theory and practice of intercultural communication: a manual. Moscow: FORUM. [in Russian]

3. Halskova, N. D. (2006). Theory of learning foreign languages. Linguodidactics and methods: A manual for students of linguistic universities and faculties of foreign languages of higher pedagogical educational institutions. Moscow: Izdatielskii tsentr «Akadiemia». [in Russian]

4. Kulykova, L., Taracenko, T. The dialogue of cultures in the theory of cross-cultural communication and the practice of teaching foreign languages. Naukovyi visnyk Melitopolskoho derzhavnoho pedahohichnoho universytety imeni Bohdana Hmelnytskoho, 1 (18), 42-46. URL: http://dspace.tnpu.edu.ua/bitstream/ 123456789/9027/1/osvita_orden.pdf. [in Ukrainian]

5. Taracenko, T. V., Riabukha, T. V., Konovalenko, T. V., Barantsova, I. O. (2016). Intercultural communication: a manual. Melitopol: MDPU. [in Ukrainian]

6. Naumenko, T. M. (2007). Ways of activating speech activity at English lessons. Anhliiska mova ta literatura, 4 , 5-8. [in Ukrainian]

7. Sadokhin, A. P. (2005). Introduction to the theory of intercultural communication. Moscow: Vysshaia shkola. [in Russian]

8. Sadokhin, A. P. (2007). Intercultural competency: concept, structure, ways of formation. Zhurnal sotsiologii $i$ sotsialnoi antropologii, Vol. X. No.1, 125-139 [in Russian].

9. Falkova, E. G. (2007). Intercultural communication in the basic concepts and definitions: Methodical manual. SPb. F-t filologii i iskustv SPbGU. [in Russian]

10. Common European Framework of Reference for Languages: Learning, Teaching, Assessment (2001). Cambridge: Council of Europe. [in English]

11. Hall, E. (1959).The Silent Language. N.Y.: Doubleday. [in English]

12. Willis, J. (1996). A Framework for Task-Based Learning. London: Longman ELT. [in English]

Рецензент: д-р пед. наук, професор Сегеда Н.А.

Information about the authors: Taracenko Tetiana Volodymyrivna tanyta3003@gmail.com

Bohdan Khmelnytsky Melitopol State Pedagogical University

20 Hetmans'ka St., Melitopol,

Zaporizhia region, 72312, Ukraine

Kulykova Liudmyla Anatoliivna kulikovaludmila621@gmail.com Bohdan Khmelnytsky Melitopol State Pedagogical University

20 Hetmans'ka St., Melitopol,

Zaporizhia region, 72312, Ukraine

\section{Список використаних джерел}

1. Безлюдна В. В. Сучасні технології навчання іноземним мовам у вищій школі. Мова і світ: сучасні тенденції викладання іноземних мов у вищій школі: зб. матеріалів $\quad$ IV Всеукрайнського науковопрактичного вебінару (29 листопада 2017 р.) URL: http://eprints.zu.edu.ua/ 25927/20-\%20Kravets.pdf (дата звернення: 22.05.2019).

2. Белая Е. Н. Теория и практика межкультурной коммуникации: учебное пособие. Москва: ФОРУМ, 2011. 208 c.

3. Гальскова Н. Д. Теория обучения иностранным языкам. Лингводидактика и методика: учеб. пособие для студ. лингв. ун-тов и фак. ин. яз. высш. пед. учеб. заведений. 3-е изд., стер. Москва: Академия, 2006. $336 \mathrm{c.}$

4. Куликова Л. А., Тарасенко Т. В. Діалог культур у теорії міжкультурної комунікації та практиці викладання іноземних мов. Науковий вісник Мелітопольського державного педагогічного університету імені Богдана Хмельницького. Серія: $\begin{array}{llll}\text { Педагогіка. 2017. № 1(18). } & \text { С. 42-46. URL: }\end{array}$ http://dspace.tnpu.edu.ua/bitstream/ 123456789/9027/1/osvita_orden.pdf (дата звернення: 22.05.2019).

5. Міжкультурна комунікація: навчальний посібник / Тарасенко Т. В., Рябуха Т. В., Коноваленко Т. В., Баранцова I. О. Мелітополь: МДПУ, 2016. 84 с.

6. Науменко Т. М. Шляхи активізації мовленнсвої діяльності на уроках англійської мови. Англійська мова та література. 2007. № 4. С. 5-8.

7. Садохин А. П. Введение в теорию межкультурной коммуникации: научн. изд. Москва: Высшая школа, 2005. $310 \mathrm{c}$

8. Садохин А. П. Межкультурная компетентность: понятие, структура, пути формирования. Журнал соичологии и сочиальной антропологи. 2007. Том Х. № 1. C. 125-139.

9. Фалькова Е. Г. Межкультурная коммуникация в основных понятиях и определениях: методическое пособие. Санкт-Петербург: Ф-т филологии и искусств СПбГУ, 2007. $77 \mathrm{c.}$

10. Common European Framework of Reference for Languages: Learning, Teaching, Assessment. Cambridge: Council of Europe, 2001. 260 p.

11. Hall E. The Silent Language. N.Y.: Doubleday, 1959. $240 \mathrm{p}$.

12. Willis Jane. A Framework for Task-Based Learning. London: LongmanELT, 1996. $160 \mathrm{p}$. 
Gostishcheva Natalia Oleksiivna angl_fil_mdpu@ukr.net

Bohdan Khmelnytsky Melitopol State Pedagogical University 20 Hetmans'ka St., Melitopol, Zaporizhia region, 72312, Ukraine

Riabukha Tetiana Valeriivna angl_fil_mdpu@ukr.net Bohdan Khmelnytsky Melitopol State Pedagogical University 20 Hetmans'ka St., Melitopol, Zaporizhia region, 72312, Ukraine

doi:

Матеріал надійшов до редакиії 30. 05. 2019 р. Прийнято до друку 26. 06. 2019 р.
Гостішева Наталія Олексіївна angl_fil_mdpu@ukr.net

Мелітопольський державний педагогічний університет імені Богдана Хмельницького вул. Гетьманська, 20, м. Мелітополь, Запорізька обл., 72312, Україна

Рябуха Тетяна Валеріївна angl_fil_mdpu@ukr.net Мелітопольський державний педагогічний університет імені Богдана Хмельницького вул. Гетьманська, 20, м. Мелітополь, Запорізька обл., 72312, Україна

doi:

Received at the editorial office 30. 05. 2019. Accepted for publishing 26. 06. 2019. 